\title{
GT-2002-30461
}

\section{PROGRESS IN SiC/SiC CERAMIC COMPOSITE DEVELOPMENT FOR GAS TURBINE HOT-SECTION COMPONENTS UNDER NASA EPM AND UEET PROGRAMS}

\author{
James A. DiCarlo \\ Hee Mann Yun, Gregory N. Morscher, and Ramakrishna T. Bhatt \\ NASA Glenn Research Center \\ Cleveland, Ohio 44135
}

\begin{abstract}
The successful application of ceramic matrix composites as hot-section components in advanced gas turbine engines will require the development of constituent materials and processes that can provide the material systems with the key thermostructural properties required for long-term component service. Much initial progress in identifying these materials and processes was made under the former NASA Enabling Propulsion Materials Program using stoichiometric Sylramic ${ }^{T M}$ silicon-carbide ( $\mathrm{SiC}$ ) fibers, 2D-woven fiber architectures, chemically vapor-infiltrated (CVI) BN fiber coatings (interphases), and SiC-based matrices containing CVI SiC interphase over-coatings, slurry-infiltrated $\mathrm{SiC}$ particulate, and melt-infiltrated (MI) silicon. The objective of this paper is to discuss the property benefits of this $\mathrm{SiC} / \mathrm{SiC}$ composite system for high-temperature engine components and to elaborate on further progress in $\mathrm{SiC} / \mathrm{SiC}$ development made under the new NASA Ultra Efficient Engine Technology Program. This progress stems from the recent development of advanced constituent materials and manufacturing processes, including specific treatments at NASA that improve the creep, rupture, and environmental resistance of the Sylramic fiber as well as the thermal conductivity and creep resistance of the CVI SiC over-coatings. Also discussed are recent observations concerning the detrimental effects of inadvertent carbon in the fiber-BN interfacial region and the beneficial effects of certain $2 \mathrm{D}$-architectures for thin-walled $\mathrm{SiC} / \mathrm{SiC}$ panels.
\end{abstract}

\section{INTRODUCTION}

As structural materials for hot-section components in advanced aerospace and land-based gas turbine engines, fiberreinforced ceramic matrix composites (CMC) offer a variety of performance advantages over current metallic superalloys and monolithic ceramics. These advantages are primarily based on the $\mathrm{CMC}$ being capable of displaying higher temperature capability for a given structural load, lower density $(\sim 30-50 \%$ metal density), and sufficient toughness for non-catastrophic failure. These properties should in turn result in many important performance benefits for turbine engines, such as reduced cooling air requirements, simpler component design, reduced weight of support structure, improved fuel efficiency, reduced emissions, higher blade frequencies, longer service life, and higher thrust. However, the successful application of $\mathrm{CMC}$ hot-section components will depend strongly on designing the $\mathrm{CMC}$ microstructural constituents so that they can synergistically provide the total CMC system with the key thermostructural property requirements for the components.

Much initial progress in identifying the proper constituent materials and processes to achieve the performance requirements of advanced combustors was made under the former NASA Enabling Propulsion Materials (EPM) program, which had as one of its primary goals the development of a $1200^{\circ} \mathrm{C}\left(2200^{\circ} \mathrm{F}\right)$ combustor liner for a high speed civil transport (HSCT). This progress centered on the development of a $\mathrm{SiC} / \mathrm{SiC}$ composite system that addresses many of the performance needs of components that need to operate at higher material temperatures than currently available with metallic superalloys. In 1999, the NASA EPM program was terminated due to cancellation of HSCT research. Subsequently the new NASA Ultra Efficient Engine Technologies (UEET) program was initiated to explore advanced technologies for a variety of civilian engine missions, including building on NASA EPM success to develop a $1315^{\circ} \mathrm{C}$ $\left(2400^{\circ} \mathrm{F}\right) \mathrm{SiC} / \mathrm{SiC}$ composite system for potentially hotter components, such as inlet turbine vanes. The objectives of this paper are to first discuss some initial property goals that NASA

This is a preprint or reprint of a paper intended for presentation at a conference. Because changes may be made before formal publication, this is made available with the understanding that it will not be cited or reproduced without the permission of the author. 
has established for hot-component ceramic composites and then to briefly review some $\mathrm{SiC} / \mathrm{SiC}$ composite data that show progress towards these goals by constituent material and process development under the NASA EPM and UEET programs.

\section{CMC REQUIREMENTS}

There are a variety of requirements that a ceramic composite must meet in order to provide hot-section components, such as liners and vanes, that can structurally operate at higher material temperatures than currently available with the best superalloys. These requirements include the use of constituent materials, geometries, and fabrication processes that yield components not only with the proper thermostructural performance, but also with the proper shapes, sizes, and functional features. Thus fiber types, fiber architectures, fiber coatings (interphases), matrix constituents, composite overcoatings, and their fabrication processes must be judiciously selected and tailored for specific components. This can be a complex undertaking because there are many compositional choices, geometric configurations, and process routes currently available for constructing a high-temperature $\mathrm{CMC}$. In order to facilitate this process, NASA EPM and UEET have selected a short list of first-order properties that the CMC must display and the key tests to evaluate these properties. These are shown in Table 1 and include properties and tests specifically related to potential performance issues for $\mathrm{CMC}$ in general and $\mathrm{SiC} / \mathrm{SiC}$ composites in particular. Because actual quantitative property requirements for various components are enginespecific and typically proprietary, the general objective has been to maximize the Table 1 properties as much as possible. It is assumed that when sufficient improvements are observed for an advanced constituent or process, more extensive efforts will be initiated by engine end-users to evaluate other properties and to perform component-specific mission cycle testing.

\section{RESULTS AND DISCUSSION}

\section{SiC/SiC Development under NASA EPM}

Based on available property data for current fibers and CMC systems, and other relevant information provided by CMC vendors, the NASA EPM program in 1994 selected $\mathrm{SiC} / \mathrm{SiC}$ composites as the best material system for use as a combustor liner for the HSCT [1]. By 1999, research and development efforts within the program further downselected the fiber, fiber coating, and matrix constituents, as well as the fiber architecture for thin-walled components, such as the HSCT combustor liner. The down-selected constituents included as-produced stoichiometric Sylramic ${ }^{\mathrm{TM}} \mathrm{SiC}$ fibers from Dow Corning; silicon-doped $\mathrm{BN}$ fiber coatings and $\mathrm{SiC}$ over-coatings, both produced by chemical vapor infiltration (CVI) at commercial CMC vendors, such as Honeywell
Advanced Composites, Inc. (HACI); and Si-SiC matrices formed by slurry casting and silicon alloy melt infiltration (MI), which can also be performed by the same vendors. Indeed, an important objective of NASA EPM was to assure that any constituent advances for $\mathrm{SiC} / \mathrm{SiC}$ be within the production capabilities of commercial vendors so that they could be quickly and easily transferred for component fabrication by engine end-users.

For the thin-walled liners, multi-fiber Sylramic tows, sized by the fiber producer with polyethylene oxide (PEO), were woven into $2 \mathrm{D}$-fabric using processes that tended to increase tow widths and to separate contacting fibers. These tow spreading processes typically resulted in better CMC thermostructural properties, such as modulus, UTS, and rupture strength at intermediate and high temperatures. The tows were then woven at vendors, such as Albany International Techniweave, Inc., into balanced 0/90 five-harness satin (5HS) fabrics with typically 20 tow ends-per-inch (epi) in the warp and fill directions. For $\mathrm{SiC} / \mathrm{SiC}$ panel and combustor liner construction, a selected number of fabric plies were then stacked, compressed, and infiltrated with the BN fiber coating and the matrix constituents by the $\mathrm{CMC}$ vendors.

During the EPM program, the only commercially available small-diameter $\mathrm{SiC}$ fiber types with sufficient high-temperature capability were the Sylramic fiber and the carbon-rich $\mathrm{Hi}$ Nicalon fiber from Nippon Carbon. However, in comparison to the Sylramic fiber, the non-stoichiometry, low process temperature, and carbon-rich surface of the Hi-Nicalon fiber resulted in reduced thermal conductivity, thermal stability, creep resistance, and environmental durability, both for individual fibers [2] and their composites. For the fiber coating, CVI BN was selected because it not only displayed sufficient compliance for CMC toughness, but also was more oxidatively resistant than traditional carbon-based coatings. When doped with silicon, the BN showed little loss in compliance, but an improvement in resistance to moisture, a degrading yet inherent constituent of combustion gas environments. Like the silicon dopant, the CVI SiC overcoating on top of the $\mathrm{BN}$ interphase provided the interphase with environmental protection. But just as importantly, the $\mathrm{SiC}$ over-coating functioned as the primary thermostructural constituent of the matrix, providing high thermal conductivity, creep resistance, and interlaminar strength. These capabilities were somewhat limited by the fact that closed and open porosity remained in the SiC over-coating after the CVI process. However, these issues were alleviated to a large degree by the remaining matrix processing steps that filled the open porosity with silicon-bonded SiC particulate. Thus, in comparison to traditional CVI SiC matrices, the EPM SiC matrix is more thermally conductive and environmentally resistant in that it does not require an oxidation-protective composite over-coating to seal open porosity. The enhanced density of the EPM matrix also increases the composite elastic 
modulus, which in turn contributes to a higher tensile stress for matrix cracking [3]. Final $\mathrm{SiC} / \mathrm{SiC}$ composite densities are typically near $2.8 \mathrm{gm} / \mathrm{cm}^{3}$.

Regarding the need for over-coatings on $\mathrm{SiC} / \mathrm{SiC}$ hot-section components, burner rig studies within the EPM program determined that a recession issue exists with the use of $\mathrm{SiC}$ in high-temperature, high-velocity, and moisture-containing environments, such as those in gas turbine engines. That is, under wet oxidizing conditions, growing silica on the $\mathrm{CMC}$ surface reacts with water to form volatile species, giving rise to paralinear oxidation kinetics and a gas velocity-dependent recession of Si-based materials [4]. For example, for a leanburn situation with combustion gases at $10 \mathrm{~atm}$ and $90 \mathrm{~m} / \mathrm{sec}$ velocity, $\mathrm{SiC}$ materials will recess $\sim 250$ and $500 \mu \mathrm{m}$ after 1000 hrs at material temperatures of $1200^{\circ} \mathrm{C}\left(2200^{\circ} \mathrm{F}\right)$ and $1315^{\circ} \mathrm{C}$ $\left(2400^{\circ} \mathrm{F}\right)$, respectively. The current remedy developed under EPM to minimize this recession issue is to use oxide-based environmental barrier coatings $(\mathrm{EBC})$ that are applied to the combustion-side surfaces of $\mathrm{SiC} / \mathrm{SiC}$ components [5].

\section{SiC/SiC Development under NASA UEET}

The general objective under NASA UEET was to further improve the performance characteristics of the $\mathrm{SiC} / \mathrm{SiC}$ composite system developed under EPM. This improvement was primarily required because the UEET focus is on components, such as inlet turbine vanes, that are envisioned to operate at $1315^{\circ} \mathrm{C}\left(2400^{\circ} \mathrm{F}\right)$. The remaining scope of this paper is to briefly discuss CMC test results that indicate UEET progress in relation to the key properties of Table 1. Particular emphasis is placed on advanced materials and processes for the four primary constituents controlling $\mathrm{SiC} / \mathrm{SiC}$ composite performance: the fiber, the fiber coating, the fiber architecture, and the matrix. The property results were obtained using test specimens machined from 8-ply $150 \times 230$ $\mathrm{mm} \mathrm{SiC/SiC} \mathrm{flat} \mathrm{panels} \mathrm{produced} \mathrm{at} \mathrm{HACI} \mathrm{using} 0 / 905 \mathrm{HS}$ fabric and total fiber fractions from 35 to $40 \%$.

Fiber. Since the end of EPM, three new types of smalldiameter near-stoichiometric $\mathrm{SiC}$ fibers other than Sylramic have become available to UEET for CMC fabrication. These include the Hi-Nicalon Type $\mathrm{S}$ (Hi-Nicalon-S) fiber from Nippon Carbon, the Tyranno SA fiber from UBE Industries, and the Sylramic-iBN fiber developed under NASA UEET. For this last fiber type, woven Sylramic fabrics with an alternate sizing other than PEO were thermally treated in a controlled environment in order to allow excess boron sintering aids to diffuse out of the fiber and to form a thin in-situ BN (iBN) layer on the fiber surface [2]. Removing boron from the fiber bulk significantly improves fiber creep, rupture, and oxidation resistance, while the in-situ BN provides a buffer layer inhibiting detrimental chemical and mechanical interactions between contacting fibers. Based on displaying a minimum strength capability in fabric testing [6], Sylramic
(PEO), Sylramic-iBN, and Hi-Nicalon-S fabrics were employed to fabricate CMC panels using standard EPM fiber coating and matrix approaches. Specimens from these CMC were then tested specifically for those Table 1 properties that are primarily fiber controlled. Test results showed that the $\mathrm{SiC} / \mathrm{SiC}$ composites reinforced by the Sylramic-iBN fiber displayed the highest UTS from 20 to $1315^{\circ} \mathrm{C}\left(70\right.$ to $\left.2400^{\circ} \mathrm{F}\right)$, the best strength retention after burner-rig exposure at $800^{\circ} \mathrm{C}\left(1470^{\circ} \mathrm{F}\right)$, the best strength retention after air exposure at high stress at $1315^{\circ} \mathrm{C}\left(2400^{\circ} \mathrm{F}\right)$, and the highest transverse thermal conductivity from 20 to $1315^{\circ} \mathrm{C}\left(70\right.$ to $\left.2400^{\circ} \mathrm{F}\right)$.

The room-temperature tensile stress-strain results for the three CMC types in their as-fabricated condition are shown in Fig. 1. The high UTS of the as-fabricated Sylramic-iBN CMC is presumably related to a high fabric strength and to the fact that the in-situ BN layer minimizes fiber/fiber contact within the tows [6]. Fiber-to fiber physical contact can be detrimental to Sylramic CMC strength due to the boron-rich chemistry of the as-produced Sylramic fiber surface. The chemistry issue for asfabricated CMC arises because the CVI BN coating process can introduce oxygen into the coating, which in turn can cause detrimental bonding of contacting fibers via enhanced silica growth. Another factor related to the high UTS of the SylramiciBN CMC is that tow spreading automatically occurs within woven fabric during the treatment process that forms the Sylramic-iBN fibers. On the other hand, the lower strength of the Hi-Nicalon-S composites can be attributed to a lower average strength for the as-produced fibers, as confirmed by fabric strength tests [7].

Fig. 2 plots tensile rupture strength results as a function of test time for the Hi-Nicalon-S and Sylramic-iBN CMC at $1315^{\circ} \mathrm{C}$ $\left(2400^{\circ} \mathrm{F}\right)$, and for a Hi-Nicalon $\mathrm{CMC}$ at $1300^{\circ} \mathrm{C}\left(2370^{\circ} \mathrm{F}\right)$ [8]. The curves were best fit to fast-fracture and stress-rupture data with the strength values normalized to a total fiber fraction of $40 \%$. It can be seen that the Sylramic-iBN CMC displayed the best strength retention for times up to 100 hours. The fact that the 500-hr rupture strength for the two CMC with nearstoichiometric fibers was $\sim 100 \mathrm{MPa}$, which is near the strength for matrix cracking, suggests that these materials have lost their composite toughness. Residual mechanical data have yet to be taken as a function of time at a given stress level. Nevertheless, it is anticipated that below $100 \mathrm{MPa}$, Sylramic-iBN CMC should retain tough behavior well beyond 500 hours.

Regarding thermal conductivity, the CMC with the two Sylramic fiber types displayed similar transverse or throughthickness values of $\sim 20$ and $11 \mathrm{~W} / \mathrm{m} \cdot{ }^{\circ} \mathrm{C}$ at room temperature and $1300^{\circ} \mathrm{C}\left(2370^{\circ} \mathrm{F}\right)$, respectively, which can be compared to values of $\sim 14$ and 9 for $\mathrm{CMC}$ with Hi-Nicalon Type S fibers. This behavior is due in most part to the larger grain sizes of the Sylramic fiber types, which in turn is related to their higher production temperatures. The larger grain sizes are sufficient to retain high fiber tensile strength, while also allowing high fiber thermal conductivity and high fiber creep resistance, provided 
little or no sintering aids remain in the grain boundaries. Thus the better creep-rupture resistance of the Sylramic-iBN CMC shown in Fig. 2 can be attributed to the grain size and reduced boron in the Sylramic-iBN fiber.

Fiber Coating. For the burner rig tests, CMC test specimens with machined edges (and exposed $90^{\circ}$ tows and fiber coatings) were subjected under $\sim$ zero stress to one-atmosphere combustion gases $(\sim 10 \%$ moisture $)$ at a gas velocity of Mach 0.3 [9]. Stress-strain results at room temperature for the three CMC types after $\sim 100$ hours of burner rig exposure at $800^{\circ} \mathrm{C}\left(1470^{\circ} \mathrm{F}\right)$ are also shown in Fig. 1. Significant degradation in UTS was seen for the Sylramic (PEO) and Hi-Nicalon-S CMC in which free carbon was found to exist on the fiber surface. Microstructural observations indicated that the flowing oxygen removed the carbon throughout the $\mathrm{CMC}$, thereby allowing oxygen and moisture to bond together contacting $\mathrm{SiC}$ fibers, even in the $0^{\circ}$ tows. The fact that Fig. 1 shows no loss in UTS for the Sylramic-iBN CMC can be attributed in part to the in-situ BN layer, which minimizes direct contact between $\mathrm{SiC}$ fibers, but primarily to the non-detection of detrimental carbon at the interface between the fiber and $\mathrm{BN}$. This can be explained by the use of a sizing other than PEO for the precursor fibers to the Sylramic-iBN fabric; whereas the Sylramic fibers originally sized with PEO were observed to have a carbon char on their surfaces within the as-fabricated CMC. Thus the loss of composite toughness for the Sylramic CMC suggests that under the selected test conditions, the Si-doped BN interphase was not completely effective in preventing oxygen ingress, carbon removal, and fiber-fiber bonding. This is supported also by the Hi-Nicalon-S CMC results because this fiber (as well as Hi-Nicalon) displayed a carbon-rich layer on its as-produced surface $[6,9]$. Thus UEET has determined that inadvertent free carbon on fiber surfaces must be avoided for combustion environments. Retention of UTS after burner rig exposure of uncracked CMC with no seal coating is currently the most definitive test for this issue.

Fiber Architecture. As discussed above, tow spreading by mechanical means or simply by the treatment used to form Sylramic-iBN fabric allows better fiber separation and reduced fiber-fiber contact, which in turn results in more consistent and high CMC modulus and UTS. Another important UEET finding concerning $2 \mathrm{D}$-woven architecture is that use of fabric with tow ends-per-inch less than the standard of 20 epi can provide advantages in terms of reduced ply height and increased ply and CMC strength [7]. The reduced ply height provides more control of part thickness by allowing more plies for a given thickness. The increased ply strength is presumably related to a reduced number of interlaced 90-degree tows, which in turn reduces the crimp angle on the high-modulus fibers in the 0-degree tows. Also, although fabric with lower epi reduced the maximum fiber fraction in an 8-ply CMC panel, CMC UTS actually increased due to increased ply strength. For example, in comparison to the data of Fig. 1, CMC with low-epi Sylramic-iBN fabric have recently displayed ultimate tensile strengths and strains of greater than $500 \mathrm{MPa}$ and $0.6 \%$, respectively. Thus using fabric with low epi has various advantages, including the achievement of a significantly higher strength per fiber fraction in thin-walled CMC components.

Matrix. For matrix optimization studies, UEET has determined that thermal annealing of CVI SiC-coated preforms prior to the slurry and MI steps improves the creep resistance and thermal conductivity of the final CMC [10]. Fig. 3 shows how the creep curves of Sylramic-reinforced composites are improved by the use of Sylramic-iBN fibers and by annealing of preforms with these fibers. Also, increases from -20 to $30 \%$ in hightemperature through-thickness thermal conductivity have been observed for CMC with annealed preforms. Both effects can be attributed to microstructural stabilization of the CVI SiC overcoating, which is deposited below the annealing temperature. Sylramic-iBN is the only fiber that survives this annealing treatment with no strength loss of the preform. However, the current CVI BN interphase coating, which is also deposited below the annealing temperature, densifies and contracts between the fiber and matrix. This in turn can cause a debonding of the $\mathrm{BN}$ coating from the matrix, as evidenced by a reduced CMC modulus of the preform and final CMC. Studies to better control this effect are on going.

\section{SUMMARY AND FUTURE DIRECTIONS}

By working closely with CMC vendors, the NASA EPM and UEET programs have identified constituent approaches that have yielded $\mathrm{SiC} / \mathrm{SiC}$ composites for application up to $1315^{\circ} \mathrm{C}$ $\left(2400^{\circ} \mathrm{F}\right)$ in advanced hot-section components. Major advances were specifically observed in the use of (1) NASA-produced Sylramic-iBN fibers, (2) Si-doped BN fiber coatings with a carbon-free interface between the fiber and BN, (3) tow spreading and low epi for 2D-woven Sylramic-iBN fabric, and (4) thermal annealing of CVI SiC-coated preforms. UEET is continuing to seek further improvements with more focused efforts toward demonstrating CMC vane sub-elements where fiber architecture is a prime concern. Clearly from the initial efforts on thin-walled panels, architectural approaches for these components will need to minimize fiber-fiber contacts and fiber bending within the final composite microstructure. As in the EPM program, UEET plans to demonstrate these constituent and architectural advances by fabrication of a controlled set of panels and sub-elements, which will then be used to generate limited property databases for $\mathrm{SiC} / \mathrm{SiC}$ component designers and endusers.

\section{REFERENCES}

1. Brewer, D., 1999, "HSR/EPM Combustor Materials Development Program", Materials Science and Engineering, A261, pp. 284-291.

2. Yun, H.M., and DiCarlo, J.A., 1999, "Comparison of the Tensile, Creep, and Rupture Strength Properties of Stoichiometric SiC Fibers", Cer. Eng. Sci. Proc., 20 [3], 259-272. 
3. Morscher, G.N., Gyekenyesi, J.Z., and Bhatt, R.T., 2000, "Damage Accumulation in 2-D Woven $\mathrm{SiC} / \mathrm{SiC}$ Ceramic Matrix Composites" in ASTM STP 1392, (Eds. M.G. Jenkins et al), ASTM, West Conshohocken, PA, USA, pp. 306-319.

4. Smialek, J.L, Robinson, R.C., Opila, E.J., Fox, D.S., and Jacobson, N.S., Adv. Composite Mater, 1999, "SiC and Si3N4 Recession Due to SiO2 Scale Volatility under Combustor Conditions", Adv. Composite Mater, 8 [1], pp. 33-45.

5. Lee, K.N., 2001, "Environmental Barrier Coatings for SiliconBased Ceramics", High Temperature Ceramic Matrix Composites, W. Krenkel, R. Naslain, and H. Schneider, Eds, Wiley-VCH, Weinheim, Germany, 2001, pp. 224- 229.

6. Yun, H.M., Gyekenyesi, J.Z., Chen, Y.L., Wheeler, D.R., and DiCarlo, J.A., 2001, "Tensile Behavior of $\mathrm{SiC} / \mathrm{SiC}$ Composites
Reinforced By Treated Sylramic SiC Fibers", Cer. Eng. Sci. Proc., 22 [3], pp. 521-531.

7. Yun, H.M., and DiCarlo, J.A., 2001, "Effects of 2-D Fabric Geometry on the Tensile Strength of Stoichiometric SiC FiberReinforced Composites", High Temperature Ceramic Matrix Composites, W. Krenkel, R. Naslain, and H. Schneider, Eds, Wiley-VCH, Weinheim, Germany, 2001, pp. 99-105.

8. Zhu, S., Mizuno, M., Kagawa, Y., Cao, J., Nagano, Y., and Kaya, H., 1999, "Creep and Fatigue Behavior in Hi-Nicalon Fiber-Reinforced Silicon Carbide Composites at High Temperatures”, J. Am. Ceram. Soc., 82 [1], pp. 117-128.

9. Ogbuji, L.T., 1998, "A Pervasive Mode of Oxidation Degradation in a $\mathrm{SiC} / \mathrm{SiC}$ Composite”, J. Am. Ceram. Soc., 81[11], pp. 2777 2784.

10. Bhatt, R.T. and Hurst, J.B., 2001, private communication.

Table 1. Key CMC property needs and tests for hot section components

\begin{tabular}{|c|c|}
\hline Key CMC Property Need & Key CMC Test \\
\hline $\begin{array}{l}\text { - High tensile strength for matrix cracking (allows high } \\
\text { design stress for elastic behavior) }\end{array}$ & \multirow[t]{2}{*}{$\begin{array}{l}\text { - Tensile stress-strain behavior of as-fabricated } \mathrm{CMC} \text { at } \\
\text { room temperature and upper use temperature }\end{array}$} \\
\hline $\begin{array}{l}\text { High ultimate tensile strength (UTS) and strain after } \\
\text { CMC fabrication (allows high damage tolerance and } \\
\text { long-term environmental durability after cracking) }\end{array}$ & \\
\hline $\begin{array}{l}\text { Stress-strain retention after interphase exposure at } \\
\text { intermediate temperatures in wet oxygen (allows CMC } \\
\text { toughness retention after exposure of machined edges } \\
\text { and/or matrix cracks to combustion gases) }\end{array}$ & $\begin{array}{l}\text { Tensile stress-strain retention for uncoated specimens } \\
\text { after burner rig exposure at } 800^{\circ} \mathrm{C}\left(1470^{\circ} \mathrm{C}\right) ; \text { Rupture } \\
\text { life and stress-strain retention of cracked } \mathrm{CMC} \text { at } 800^{\circ} \mathrm{C} \\
\left(1470^{\circ} \mathrm{C}\right) \text { in air and moisture }\end{array}$ \\
\hline $\begin{array}{l}\text { High creep resistance, rupture resistance, and UTS } \\
\text { retention at all service temperatures (allows long life, } \\
\text { dimensional control, low residual stress, resistance to hot } \\
\text { spots, and toughness retention) }\end{array}$ & $\begin{array}{l}\text { - Creep strain versus time, rupture life versus stress, and } \\
\text { stress-strain retention at upper use temperature }\end{array}$ \\
\hline $\begin{array}{l}\text { - High interlaminar strength (allows high through-thickness } \\
\text { shear and tensile stresses) }\end{array}$ & $\begin{array}{l}\text { - Interlaminar shear and tensile strength at room } \\
\text { temperature and upper use temperature }\end{array}$ \\
\hline $\begin{array}{l}\text { - High transverse and axial thermal conductivity (reduces } \\
\text { thermal stresses due to gradients/shock) }\end{array}$ & $\begin{array}{l}\text { - Thermal conductivity at room temperature and upper } \\
\text { use temperature }\end{array}$ \\
\hline
\end{tabular}




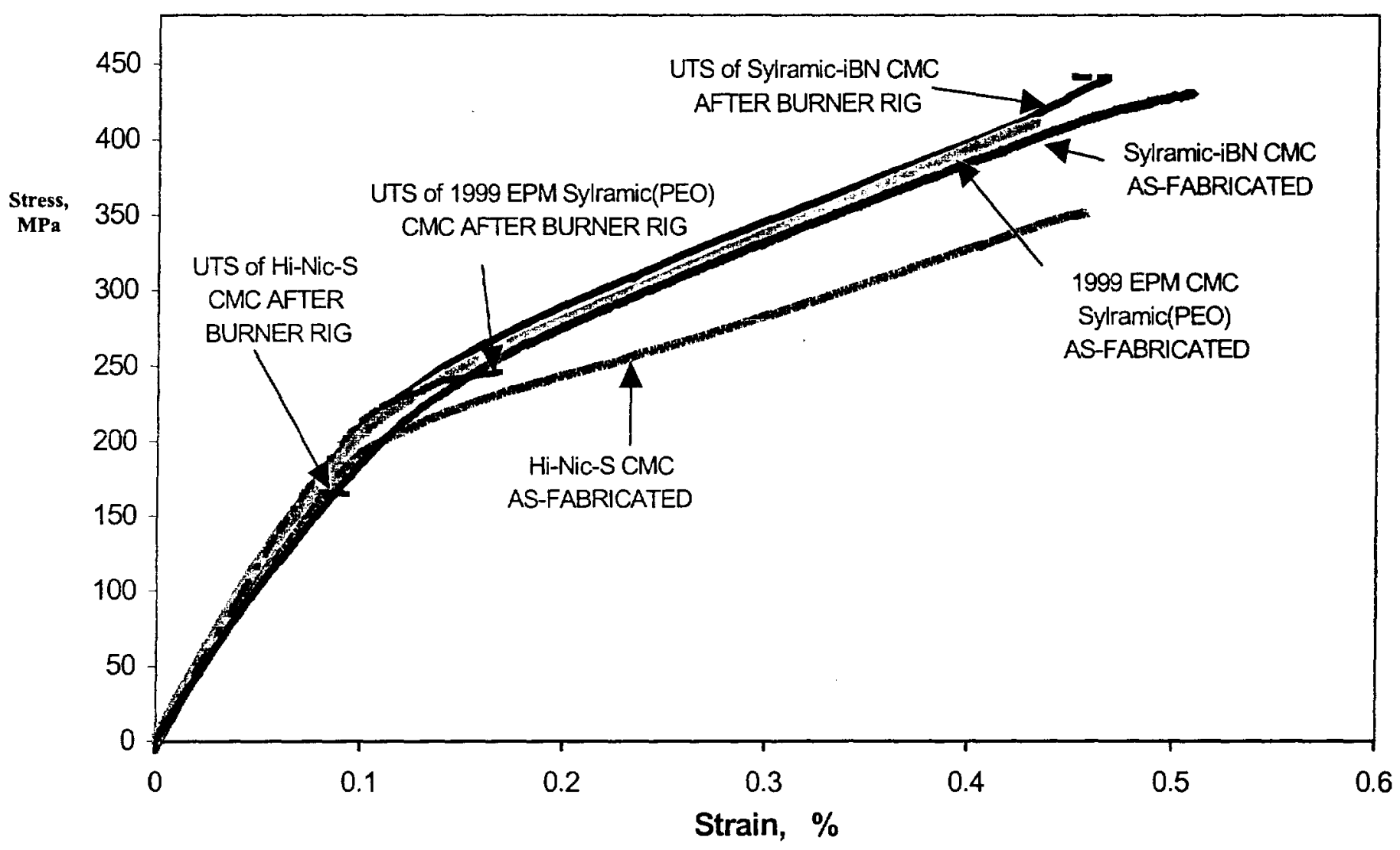

Figure 1. Stress-strain behavior at room temperature for SiC/SiC CMC after fabrication and after $\sim 100$-hr burner rig exposure at $800^{\circ} \mathrm{C}\left(1470^{\circ} \mathrm{F}\right)$. 


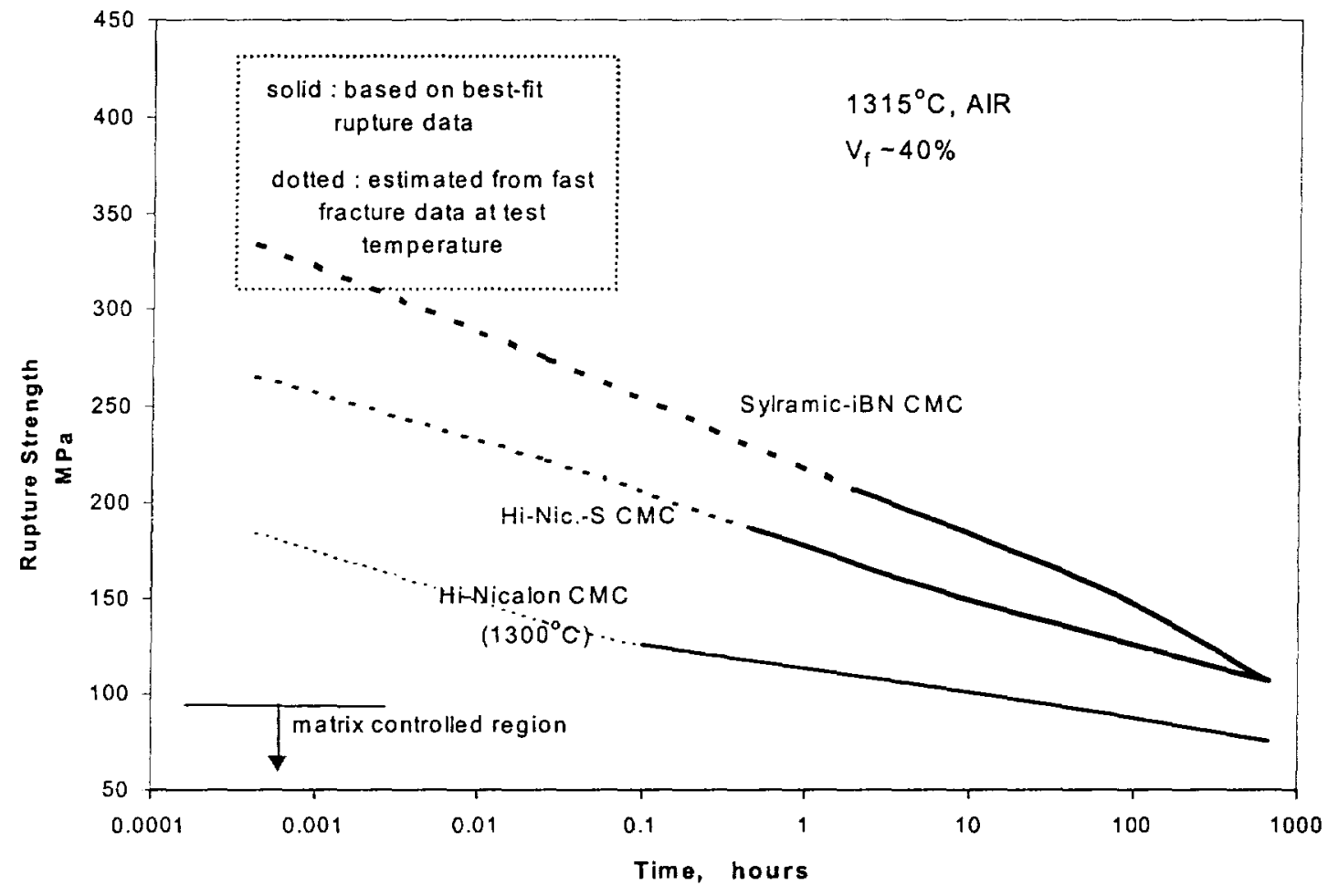

Figure 2. Best-fit stress rupture results in air for $\mathrm{SiC} / \mathrm{SiC} \mathrm{CMC}$ at $1315^{\circ} \mathrm{C}\left(2400^{\circ} \mathrm{F}\right)$ and $1300^{\circ} \mathrm{C}\left(2370^{\circ} \mathrm{F}\right)[9]$. Strengths were normalized to $40 \%$ fiber volume fraction.

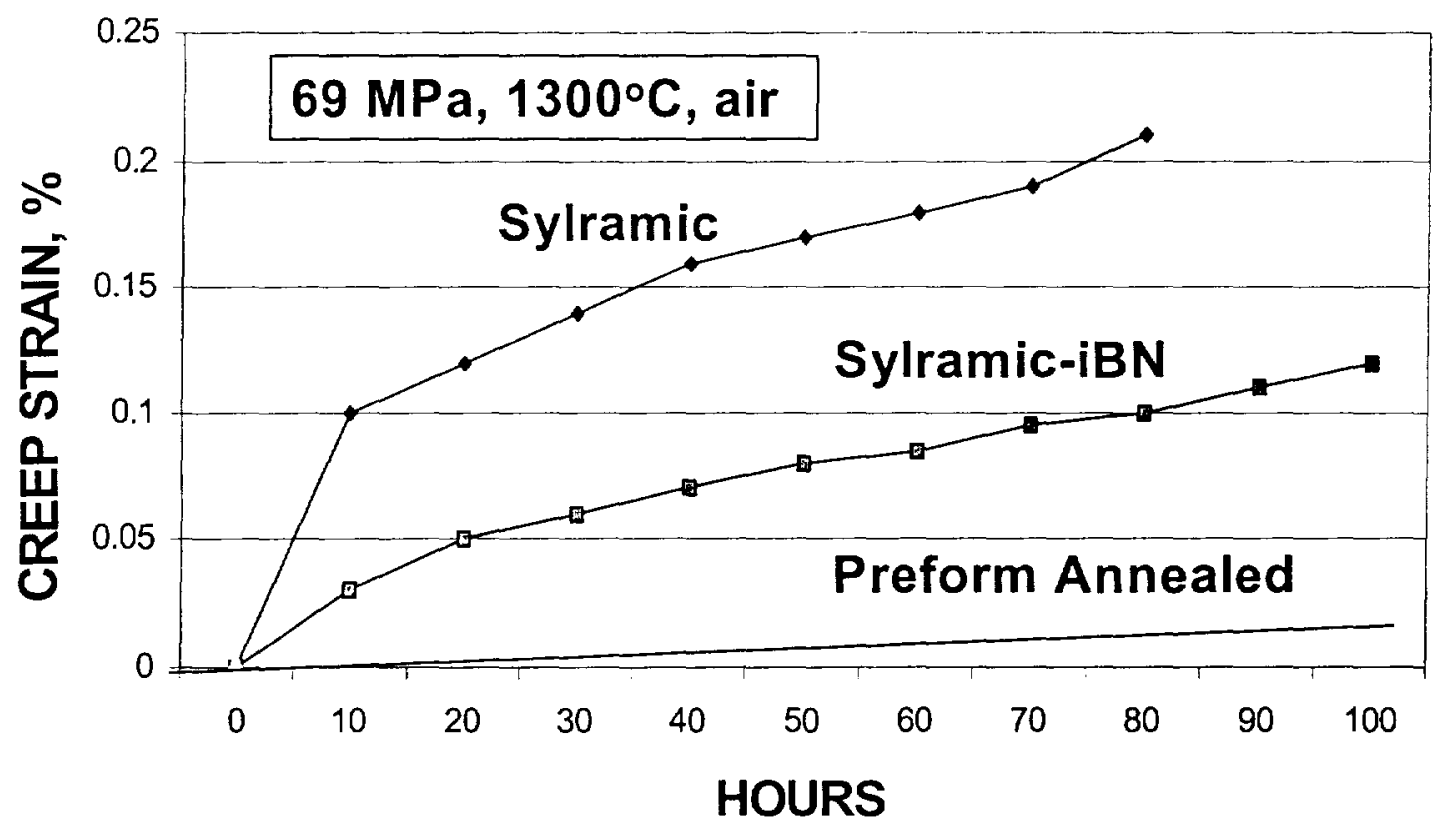

Figure 3. Creep in air at $1300^{\circ} \mathrm{C}\left(2370^{\circ} \mathrm{F}\right)$ for SiC/SiC CMC with Sylramic and Sylramic-iBN fibers and with Sylramic-iBN/CVI-SiC preforms that were thermally annealed prior to slurry and silicon melt infiltration. 